\title{
Purification of mouse sperm acrosin, its activation from proacrosin and effect on homologous egg investments
}

\author{
C. R. Brown \\ A.R.C. Institute of Animal Physiology, Animal Research Station, 307 Huntingdon Road, \\ Cambridge CB3 OJQ, U.K.
}

\begin{abstract}
Summary. When proacrosin from mouse epididymal spermatozoa was activated a single form of acrosin was produced. The enzyme was isolated by gel filtration followed by affinity chromatography using Sepharose-4B linked to an acrosin inhibitor $p-\left(p^{\prime}-\right.$ aminophenoxypropoxy)benzamidine. The molecular weight of partly purified acrosin was 53000 by gel filtration, and of the pure enzyme 39000 by SDS-polyacrylamide gel electrophoresis. Pure mouse acrosin removed the cumulus oophorus, corona radiata and zona pellucida from the homologous egg. It is proposed that penetration of spermatozoa through egg investments, particularly through the zona pellucida, is a simpler process in the mouse than in the sheep.
\end{abstract}

\section{Introduction}

The contention that the digestive action of the acrosomal proteinase, acrosin (EC 3.4.21.10), on the egg zona pellucida is the means by which the spermatozoon is able to penetrate this investment during fertilization has recently been subject to scrutiny (Bedford \& Cross, 1978). The main evidence in support of the proposition is that inhibitors of proteinase activity impair fertilization in vivo and in vitro (Stambaugh \& Buckley, 1969; Stambaugh, Brackett \& Mastroianni, 1969; Zaneveld, Robertson, Kessler \& Williams, 1971; Yang, Zaneveld \& Schumacher, 1976; Beyler \& Zaneveld, 1982; Fraser, 1982), and that preparations of acrosin will, under certain experimental conditions, remove the zona pellucida from the ovum (Stambaugh, \& Buckley, 1969; Meizel \& Mukerji, 1976; Brown, 1982). However, the inhibitors used were not specific to acrosin and tests on the ability of acrosin to disperse the zona pellucida have often been carried out with impure enzyme in a non-physiological medium or with acrosin and egg from different species. Furthermore, there is evidence of a role for acrosin either in the acrosome reaction itself (Lui \& Meizel, 1979) or in dispersal of the acrosomal matrix once this reaction has occurred (Green, 1978).

It has been demonstrated that under conditions in vitro, akin to physiological, pure ram $\beta$ acrosin will not remove the zona pellucida from the sheep egg whereas it will rapidly remove all investments from the mouse egg (Brown, 1982). This observation suggests that, in the sheep, sperm penetration of the zona pellucida is aided by enzymes other than, or in addition to, acrosin. It also suggests that the mouse zona pellucida might be demonstrably susceptible to pure mouse acrosin. Since this has not previously been tested the present paper describes the complete purification of mouse acrosin and its effect on the investments of homologous eggs. Because mouse acrosin is unstable and present in spermatozoa in small amounts it was necessary to accrue the enzyme in its stable zymogen form, proacrosin, before purification studies. This was achieved by collecting and storing spermatozoa in a medium containing $p$-aminobenzamidine, an inhibitor of acrosin which also reversibly blocks the activation of proacrosin to acrosin (Brown \& Harrison, 1978). Consequently, new data on the activation of mouse proacrosin are also presented. 


\section{Materials and Methods}

\section{Collection and preparation of epididymal spermatozoa}

Epididymides were excised from freshly killed 3-4-month-old Carworth Europe CLFP noninbred mice and the cauda epididymidis diced with a scalpel in $0.264 \mathrm{M}$-sucrose, $5 \mathrm{mM}$-MES, $0 \cdot 5$ mM- $p \mathrm{AB}$ ( $p$-aminobenzamidine hydrochloride) $\mathrm{pH} 6 \cdot 5$ (sucrose- $p \mathrm{AB}$ buffer), at $20^{\circ} \mathrm{C}$. Spermatozoa were collected from groups of 50 mice and diluted into $20 \mathrm{ml}$ buffer, filtered through siliconized glass wool to remove contaminating tissue and centrifuged for $30 \mathrm{~min}$ at $3000 \mathrm{~g}\left(4^{\circ} \mathrm{C}\right)$. Spermatozoa were then resuspended in approximately $4 \mathrm{ml}$ sucrose- $p \mathrm{AB}$ buffer and stored at $-20^{\circ} \mathrm{C}$ until use. When needed, the spermatozoa were thawed, diluted in sucrose-pAB to approximately $2 \times 10^{8}$ cells $/ \mathrm{ml}$ and denuded, i.e. the outer acrosomal membrane and acrosomal contents were released by vortex mixing (Brown, Andani \& Hartree, 1975). This procedure, which also releases endogenous acrosin inhibitor(s) (Hartree, 1977), results in little or no proacrosin being lost from the spermatozoa. Denuded spermatozoa were then washed free of $p \mathrm{AB}$ and detached cell components by centrifuging ( $25 \mathrm{~min}$ at $1500 \mathrm{~g}$ ) $2 \mathrm{ml}$ aliquants through $8 \mathrm{ml}$ steps of $0.3 \mathrm{M}$-sucrose, $5 \mathrm{mM}$-MES, $\mathrm{pH} 6.0$ and resuspended in appropriate medium for each experiment.

\section{Collection of eggs}

Eggs were collected into a balanced medium (Brown, 1982) from the oviducts of 26-28-day-old CLFP mice treated previously with 12 i.u. PMSG (48 h) and 12 i.u. hCG $(18 \mathrm{~h})$, and used without delay. The eggs were left in the cumulus, denuded of all but the corona radiata, or freed entirely of follicle cells by gentle suction into and out of a fine-bored Pasteur pipette to leave the zona pellucida outermost. Incubations with enzyme were carried out on siliconized watch glasses.

\section{Incubation of eggs with acrosin}

Preliminary experiments showed purified mouse acrosin to be very unstable at physiological $\mathrm{pH}$; thus the enzyme, when adjusted to $\mathrm{pH} 7.4$ with Hepes, lost approximately $50 \%$ of its activity after $5 \mathrm{~min}$ at $37^{\circ} \mathrm{C}$ and $90 \%$ after $40 \mathrm{~min}$. Because of this instability egg-acrosin incubations were carried out as follows. Eggs, with cumulus oophorus or corona radiata or the zona pellucida outermost, were collected into groups of 12-15 in approximately $10 \mu \mathrm{l}$ medium (see 'Materials and Methods'). Acrosin, freshly purified, was kept at $4^{\circ} \mathrm{C}$ in $0.15 \mathrm{M}-\mathrm{NaCl}, 5 \mathrm{mM}-\mathrm{CaCl}_{2}$ pH 2.6 and an aliquant $(8 \mu \mathrm{l})$ was adjusted to $\mathrm{pH} 7.4$ with $0.4 \mu \mathrm{l} 0.2 \mathrm{M}$-Hepes $\mathrm{pH} 7.7$. This was added without delay to the eggs in medium, the mixture covered with liquid paraffin at $37^{\circ} \mathrm{C}$ and incubated at $37^{\circ} \mathrm{C}$ for $40 \mathrm{~min}$. The eggs were then transferred in approximately $10 \mu \mathrm{l}$ medium to a freshly neutralized $8 \mu 1$ aliquant of acrosin, covered in liquid paraffin, and the incubation at $37^{\circ} \mathrm{C}$ continued. This process was repeated at $40 \mathrm{~min}$ intervals during which observations on the egg investments were made. Control eggs, grouped according to which investment was outermost, received the same treatment less enzyme.

\section{Acrosin assays}

Fluorometric assays with benzoylarginine-2-naphthylamide (BANA) as substrate were carried out essentially as described by Brown \& Hartree (1976). Assays were at $25^{\circ} \mathrm{C}$ in a system $(0.5 \mathrm{ml})$ containing $50 \mathrm{~mm}$-Tris- $\mathrm{HCl}, 0 \cdot 2 \mathrm{M}-\mathrm{CaCl}_{2}, 10 \% \mathrm{v} / \mathrm{v}$ dimethylsulphoxide, $1 \mathrm{~mm}-\mathrm{BANA}$ and sample, pH 8.2. The fluorometer was calibrated with $0-50 \mathrm{pmol} 2$-naphthylamine measured in the assay system (less enzyme only). Enzyme activity is expressed in $\mathrm{mU}$, i.e. nmol BANA hydrolysed per min, unless stated otherwise. 


\section{Electrophoretic analyses}

Electrophoresis on non-denaturing polyacrylamide gels $(70 \mathrm{~mm} \times 6 \mathrm{~mm})$ at $\mathrm{pH} 4.9$ and subsequent detection of acrosin and proacrosin in gels with benzoylarginine-2-naphthylamide and Fast Garnet GBC was carried out as detailed by Harrison (1982).

Electrophoresis on $12 \%$ polyacrylamide gels containing SDS was carried out under reducing and non-reducing conditions according to Jones, Brown, Von Glos \& Parker (1980). Molecular weight standards were bovine serum albumin $(67000)$, ovalbumin $(43000)$, carbonic anhydrase (30 000), soybean trypsin inhibitor (20 100) and $\alpha$-lactalbumin (14 400). Proteins were detected with a silver stain by the method of Poehling \& Neuhoff (1981).

\section{Gel filtration on Sephadex 6100}

A column $\left(90 \mathrm{~cm} \times 2 \mathrm{~cm}^{2}\right)$ was calibrated with bovine serum albumin $(67000)$, ovalbumin (43 000), chymotrypsinogen (25000) and ribonuclease $(13700)$. The void volume was determined with blue dextran, and the column buffer was $0.15 \mathrm{M}-\mathrm{NaCl}, 5 \mathrm{mM}-\mathrm{CaCl}_{2} \mathrm{pH} 2 \cdot 6$. Fractions of $2 \mathrm{ml}$ were collected in plastic tubes at a flow-rate of $12 \mathrm{ml} / \mathrm{h}$ and all runs were at $4^{\circ} \mathrm{C}$. The method of Andrews (1964) was used to estimate the molecular weight of acrosin.

\section{Affinity chromatography}

Acrosin, partly purified by chromatography on Sephadex-G100, was isolated using a column $\left(6 \mathrm{~cm} \times 1 \mathrm{~cm}^{2}\right)$ of Sepharose-4B linked to an acrosin inhibitor $p$-( $p^{\prime}$-aminophenoxypropoxy) benzamidine (Brown \& Hartree, 1978). The design of subsequent egg-acrosin tests required that buffers used for binding and elution of acrosin were modified from those previously described. Therefore the column was equilibrated for binding with $0.15 \mathrm{M}-\mathrm{NaCl}, 5 \mathrm{~mm}-\mathrm{CaCl}_{2}, 5 \mathrm{~mm}$-Tris $\mathrm{pH} 8$, and the enzyme was eluted with $0 \cdot 15 \mathrm{M}-\mathrm{NaCl}, 5 \mathrm{~mm}-\mathrm{CaCl}_{2} \mathrm{pH} 2 \cdot 6$. Application and elution of sample was at $4^{\circ} \mathrm{C}$ at a flow rate of $8 \mathrm{ml} / \mathrm{h}$.

\section{Results}

Time-course and electrophoretic analysis of the activation of mouse epididymal sperm proacrosin

As a preliminary step in the purification of mouse sperm acrosin it was necessary to study the time-course of proacrosin activation and observe the active enzyme form(s) produced in a suspension of denuded spermatozoa (Text-fig. 1). Since there was no acrosin in the supernatant from which the denuded spermatozoa were centrifuged (as revealed by incubating the supernatant at pH 3 before enzyme assay) it appears that there is no active enzyme present in the intact spermatozoon. Activation proceeded rapidly after removal of $p$-aminobenzamidine to give maximum activity after 40-60 min. When the activation was followed on non-denaturing polyacrylamide gel electrophoresis, only a single molecular species of acrosin was seen, slightly more basic than proacrosin (Text-fig. 1). The active species of acrosin was detectable after 10-min incubation at a time when total enzyme activity had reached only $10 \%$ of the maximum as measured by BANA hydrolysis. Throughout the entire activation process the charge on the active species remained unaltered.

\section{Purification of acrosin from mouse epididymal spermatozoa}

Denuded spermatozoa $\left(4.5 \times 10^{9}\right)$ from 400 mice were washed free of $p$ AB (see 'Materials and Methods') and resuspended in $28 \mathrm{ml} \mathrm{0.264} \mathrm{M-sucrose,} 2 \mathrm{~mm}-\mathrm{Hepes} \mathrm{pH} \mathrm{7.5}$. They were incubated at $25^{\circ} \mathrm{C}$ until maximum acrosin activity was reached (Text-fig. 1), made $0.15 \mathrm{M}$ in $\mathrm{NaCl}, 5 \mathrm{~mm}$ in 


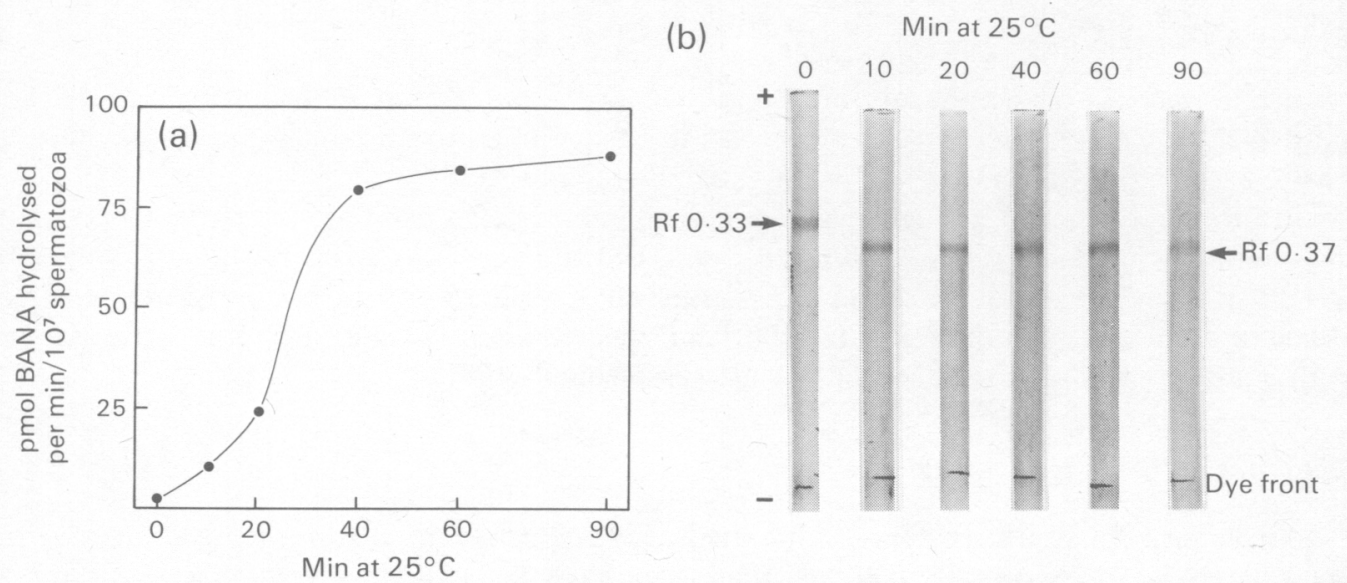

Text-fig. 1. Time-course (a) and electrophoretic analysis (b) of the activation of mouse epididymal proacrosin. Epididymal spermatozoa from 75 mice were denuded, washed free of $p \mathrm{AB}$ (see 'Materials and Methods') and resuspended at a concentration of $8 \times 10^{7} \mathrm{cells} / \mathrm{ml}$ in 6 $\mathrm{ml} 0.264 \mathrm{M}$-sucrose, $2 \mathrm{mM}$-Hepes $\mathrm{pH} 7.5$ at $25^{\circ} \mathrm{C}$. At timed intervals $1.0 \mathrm{ml}$ aliquants were centrifuged $\left(4^{\circ} \mathrm{C}, 10000 \mathrm{~g}\right.$ ) for 5 min and pelleted spermatozoa were resuspended in $0.15 \mathrm{ml}$ $0.25 \mathrm{M}$-sucrose- $\mathrm{HCl} \mathrm{pH} 2 \cdot 6$. After $30 \mathrm{~min}$ at $4^{\circ} \mathrm{C}$ the suspensions were centrifuged at $10000 \mathrm{~g}$ and the supernatants containing the proacrosin-acrosin were assayed for acrosin activity and analysed on non-denaturing polyacrylamide gels at $\mathrm{pH} 4.9$. Each gel received $0.1 \mathrm{ml}$ proacrosin-acrosin preparation containing $0.6 \mathrm{mU}$ potential activity.

$\mathrm{CaCl}_{2}$ and then acidified to $\mathrm{pH} 2.6$ with $1 \mathrm{~N}$-hydrochloric acid. After $40 \mathrm{~min}$ at $4^{\circ} \mathrm{C}$ they were centrifuged for $40 \mathrm{~min}$ at $30000 \mathrm{~g}\left(4^{\circ} \mathrm{C}\right)$ and the supernatant concentrated to $3 \mathrm{ml}$ in an Amicon ultrafiltration cell fitted with a PM10 membrane. This preparation, containing $38 \mathrm{mU}$ acrosin activity, was passed through the Sephadex G100 column to ensure complete removal of inhibitors. It emerged as a single peak with $24 \mathrm{mU}$ activity and with a molecular weight of 53000 . Acrosincontaining fractions were pooled and concentrated in the ultrafiltration cell to $3 \mathrm{ml}$, adjusted to 5 $\mathrm{mM}$ in $\mathrm{CaCl}_{2}$ and then to $\mathrm{pH} 8$ with careful addition of $1 \mathrm{M}$-Tris. Without delay it was applied to the Sepharose 4B-p-( $p^{\prime}$-aminophenoxypropoxy) benzamidine column, which was then washed thoroughly with $0 \cdot 15 \mathrm{M}-\mathrm{NaCl}, 5 \mathrm{~mm}-\mathrm{CaCl}_{2}, 5 \mathrm{~mm}$-Tris $\mathrm{pH}$. The total wash through contained only a trace of acrosin activity. Bound acrosin was then eluted with $0 \cdot 15 \mathrm{M}-\mathrm{NaCl}, 5 \mathrm{~mm}-\mathrm{CaCl}_{2} \mathrm{pH} 2 \cdot 6$ and fractions containing activity were combined, adjusted to $\mathrm{pH} 2.6$ with $\mathrm{HCl}$ and concentrated to $200 \mu \mathrm{l}$ in an Amicon ultrafiltration cell fitted with a PM10 membrane.

This preparation contained $12 \mathrm{mU}$ acrosin activity and gave a protein band with a molecular weight of 39000 when electrophoresed under reducing and non-reducing conditions on SDSpolyacrylamide gels followed by silver staining (Text-fig. 2).

\section{Effect of pure mouse acrosin on the investments of mouse eggs}

In the presence of enzyme the cumulus oophorus began to disperse within a few minutes and by $15 \mathrm{~min}$ both it and the corona radiata were completely removed. After this time investments on the relevant control eggs were retained. By $1.5 \mathrm{~h}$ erosion of the outer surface of the zona pellucida was evident and by $6 \mathrm{~h}$ the investment was completely removed. The zona pellucida of control eggs by this time was visibly unaffected. Effects of pure acrosin were very consistent from egg to egg. Inspection of control eggs after a further $14 \mathrm{~h}$ showed the zona pellucida and corona radiata to be present and of normal appearance, whilst the cumulus oophorus had dispersed.

To confirm that dispersal of the cumulus oophorus and corona radiata was acrosin-mediated the effect of the acrosin inhibitor p-aminobenzamidine was tested. At $5 \mathrm{~mm}$ concentration it prevented 


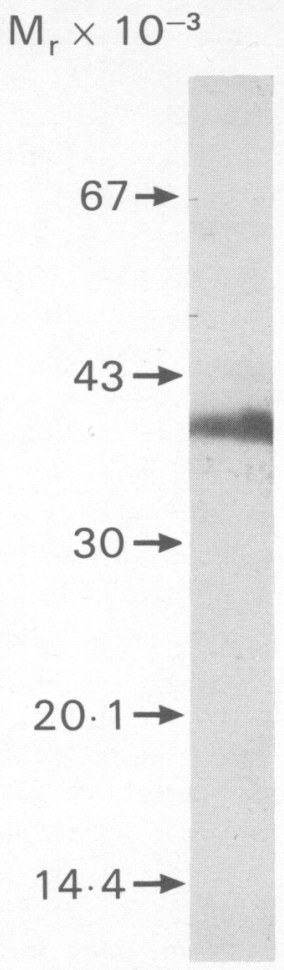

Text-fig. 2. SDS-polyacrylamide gel electrophoretogram of mouse acrosin purified by gel filtration on Sephadex G-100 and affinity chromatography on Sepharose 4B-p-( $p^{\prime}$-aminophenoxypropoxy) benzamidine.

dispersal of both investments (in tests on the corona, the cumulus had first been removed mechanically); after $4 \mathrm{~h}$ (longer times not tested) in the presence of enzyme and inhibitor the investments remained intact, whereas in enzyme alone both were removed within $15 \mathrm{~min}$.

\section{Discussion}

Detailed data on the conversion of proacrosin to acrosin in rodent species, particularly the mouse, are lacking. Bhattacharyya, Goodpasture \& Zaneveld (1979) detected significant amounts of acrosin in mouse epididymal spermatozoa but the present results indicate that virtually all the enzyme is present in the zymogen form because no active acrosin could be detected in spermatozoa freed of $p$-aminobenzamidine or in fractions derived from denuded spermatozoa. Thus, mouse spermatozoa appear to be similar to those of several other species such as ram, bull and boar (Brown \& Harrison, 1978). The time taken for mouse sperm proacrosin to fully activate (40 $\mathrm{min})$ is also similar to that seen in other species, but the transformation of the zymogen to the enzyme appears to be unusual in that it is a single-stage process which occurs before the enzyme acquires full catalytic activity (Text-fig. 1). This delay was not due to interference by acrosin inhibitor slowing down the transformation. If this was the case, proacrosin as well as acrosin would have been visualized in gels of partly activated samples, for instance after $10 \mathrm{~min}$ activation (Text-fig. 1). It is more likely that this delay in development of full catalytic activity reflects a change in the configuration of the acrosin molecule which involves no further change in charge. In other species 
so far examined the activation of sperm proacrosin generates multiple forms of acrosin which vary in stability. Usually one form is sufficiently stable to predominate, making its isolation possible, as in the case of ram $\beta$-acrosin (Brown \& Hartree, 1978). It would seem reasonable to suppose that these dominant forms of acrosin are those which function in vivo, but this remains to be proved; all forms could function together, although it is possible that a minor and/or transient form could play a key role, especially forms that are generated in the early stages of proacrosin activation. Therefore, a degree of uncertainty must exist as to the physiological relevance of one enzyme form which is selected from a number for tests in acrosin-egg incubations in vitro. In the mouse there is no such uncertainty because the activation of proacrosin produces only a single form of enzyme.

The inherent instability of mouse acrosin (Brown \& Hartree, 1976) and its presence in spermatozoa in comparatively low amounts have together made its isolation difficult. Although the purification procedure was carried through without delay and the length of time that the enzyme was subjected to $\mathrm{pH} 8$ for affinity chromatography kept to a minimum, there was an overall loss of $68 \%$ of enzyme. This loss was not, however, as dramatic as the inactivation of the pure enzyme in egg-incubation medium at $37^{\circ} \mathrm{C}$. The value of 39000 for the molecular weight of pure mouse acrosin as determined by SDS-polyacrylamide gel electrophoresis differed considerably from that of the partly purified preparation (mol. wt 53000 ) repeatedly obtained by gel filtration at $\mathrm{pH} 2 \cdot 6$. There may be two possible explanations for this. Firstly, the higher value may reflect a high carbohydrate content of the molecule. For example, pure boar acrosin, which contains $10 \%$ carbohydrate, has an apparent molecular weight of 56000 by gel filtration (Fink, Schiessler, Arnhold \& Fritz, 1972) and one of 38000 by SDS-polyacrylamide gel electrophoresis (Schleuning \& Fritz, 1974). Ram $\beta$-acrosin, with $3 \%$ carbohydrate, also shows a similar but smaller discrepancy and exhibits molecular weights of 45000 and 38000 by the respective methods (Brown \& Hartree, 1978). Alternatively, the partly purified enzyme may, during gel filtration at $\mathrm{pH} 2 \cdot 6$, bind with a protein of lower molecular weight which is subsequently dissociated at $\mathrm{pH} 8$ and separated from acrosin on the affinity column.

Inhibition of mouse in-vitro fertilization by synthetic acrosin inhibitors has been demonstrated. In one study (Beyler \& Zaneveld, 1982) a range of inhibitors, which included $p$-aminobenzamidine, all prevented fertilization, the effectiveness of each inhibitor being commensurate with its ability to inhibit a partly purified mouse acrosin. This showed the action of a proteinase(s), probably acrosin, to be crucial in the fertilization process but cast no light on whether the enzyme(s) functions during the acrosome reaction and subsequent dispersal of the acrosomal matrix or during sperm penetration of egg investments. In another study to test the effect of $p$-aminobenzamidine on invitro fertilization of zona-free and zona-intact eggs, the results were consistent with a role for a $p$ aminobenzamidine-sensitive proteinase in penetration of the zona pellucida (Fraser, 1982). However, since the inhibitors used in both studies were not acrosin-specific the results were suggestive but not conclusive.

The present results show that in a physiological medium pure mouse acrosin will digest and completely remove the zona pellucida from homologous eggs as well as disperse the corona radiata and cumulus oophorus. This clearly indicates a role for mouse acrosin in digestion of the zona pellucida and also implies that hydrolases other than acrosin are unnecessary for sperm penetration in the mouse, although they may be needed for maximum efficiency of penetration. However, very little is known of the hydrolase content of the mouse sperm acrosome, that is, whether or not it sequesters a range of enzymes similar to those detected in other species (McRorie \& Williams, 1974). Mouse acrosin dispersed the cumulus oophorus and corona radiata much more rapidly than it removed the zona pellucida, which was also the case when the effect of pure ram acrosin on mouse egg investments was tested (Brown, 1982). The difficulty in obtaining pure mouse acrosin precluded tests on its effect at higher concentrations, but it is most likely that these would have removed the zona pellucida more rapidly (Brown, 1982). The level of enzyme activity actually used in the present tests on the zona pellucida was approximately equivalent to that of ram acrosin used at $0.03 \mathrm{mg} / \mathrm{ml}$, based upon a comparable hydrolysis of benzoylarginine-2-naphthylamide by the two 
enzymes. At these comparable levels of activity ram acrosin took more than $18 \mathrm{~h}$ to remove the mouse zona pellucida (Brown, 1982) and in the present tests mouse acrosin took $6 \mathrm{~h}$. This represents a more effective hydrolysis by the homologous enzyme, especially when its instability at $\mathrm{pH} 7.4$ is taken into account. However, the zona pellucida could be subjected to much higher concentrations of acrosin in vivo (Brown, 1982).

The contrasting susceptibility of mouse and sheep zona pellucida to a pure homologous acrosin correlates with the widely different degrees of difficulty in carrying out successful in-vitro fertilization in these species. In the mouse, for example, in-vitro fertilization is readily achieved but in sheep, and other large domesticated species, it has not yet proved possible; failure has been due to the inability of the spermatozoon to penetrate the zona pellucida.

\section{References}

Andrews, P. (1964) Estimation of the molecular weights of proteins by Sephadex gel filtration. Biochem. J.91, 222-233.

Bedford, J.M. \& Cross, N.L. (1978) Normal penetration of rabbit spermatozoa through a trypsin- and acrosinresistant zona pellucida. J. Reprod. Fert. 54, 385392.

Beyler, S.A. \& Zaneveld, L.J.D. (1982) Inhibition of invitro fertilization of mouse gametes by proteinase inhibitors. J. Reprod. Fert. 66, 425-431.

Bhattacharyya, A.K., Goodpasture, J.D. \& Zaneveld, L.J.D. (1979) Acrosin of mouse spermatozoa. Am. J. Physiol. 237, E40-E44.

Brown, C.R. (1982) Effects of ram sperm acrosin on the investments of sheep, pig, mouse and gerbil eggs. $J$. Reprod. Fert. 64, 457-462.

Brown, C.R. \& Harrison, R.A.P. (1978) The activation of proacrosin in spermatozoa from ram, bull and boar. Biochem. Biophys. Acta 526, 202-217.

Brown, C.R. \& Hartree, E.F. (1976) Identification of acrosin in mouse spermatozoa. J. Reprod. Fert. 46, 249-251.

Brown, C.R. \& Hartree, E.F. (1978) Studies on ram acrosin. Activation of proacrosin accompanying the isolation of acrosin from spermatozoa and purification of the enzyme by affinity chromatography. Biochem. J. 175, 227-238.

Brown, C.R., Andani, Z. \& Hartree, E.F. (1975) Studies on ram acrosin. Isolation from spermatozoa, activation by cations and organic solvents, and influence of cations on its reaction with inhibitors. Biochem. $J$, 149, $133-146$.

Fink, E., Schiessler, H., Arnhold, M. \& Fritz, H. (1972) Isolierung eines Trypsin-ähnlichen Enzyms (Akrosin) aus Eberspermien. Hoppe-Seyler's Z. Physiol. Chem. 353, 1633-1637.

Fraser, L.R. (1982) p-Aminobenzamidine, an acrosin inhibitor, inhibits mouse sperm penetration of the zona pellucida but not the acrosome reaction. $J$. Reprod. Fert. 67, 185-194.

Green, D.P.L. (1978) The activation of proteolysis in the acrosome reaction of guinea-pig sperm. J. Cell Sci. 32, 153-164.
Harrison, R.A.P. (1982) The interaction of ram proacro$\sin$ and acrosin forms with antiserum raised against ram $m \beta$-acrosin. J. Reprod. Immun. 4, 231-249.

Hartree, E.F. (1977) Spermatozoa, eggs and proteinases. Biochem. Soc. Trans. 5, 375-394.

Jones, R., Brown, C.R., Von Glos, K.I. \& Parker, M.G. (1980) Hormonal regulation of protein synthesis in the rat epididymis. Characterization of androgendependent and testicular fluid-dependent proteins. Biochem. J. 188, 667-676.

Lui, C.W. \& Meizel, S. (1979) Further evidence in support of a role for hamster sperm hydrolytic enzymes in the acrosomal reaction. J. exp. Zool. 297, 173-186.

McRorie, R.A. \& Williams, W.L. (1974) Biochemistry of mammalian fertilization. A. Rev. Biochem. 43, 777803.

Meizel, S. \& Mukerji, S.K. (1976) Biochemical studies of proacrosin and acrosin from hamster cauda epididymal spermatozoa. Biol. Reprod. 14, 444-450.

Poehling, H.M. \& Neuhoff, V. (1981) Visualization of proteins with a silver "stain": a critical analysis. Electrophoresis 2, 141-147.

Schleuning, W.D. \& Fritz, H. (1974) Some characteristics of highly purified boar sperm acrosin. Hoppe-Seyler's Z. Physiol. Chem. 355, 125-130.

Stambaugh, R. \& Buckley, J. (1969) Identification and subcellular localization of the enzymes affecting penetration of the zona pellucida by rabbit spermatozoa. J. Reprod. Fert. 19, 423-432.

Stambaugh, R., Brackett, B.C. \& Mastroianni, L. (1969) Inhibition of in vitro fertilization of rabbit ova by trypsin inhibitors. Biol. Reprod. 1, 223-227.

Yang, S.L., Zaneveld, L.J.D. \& Schumacher, G.F.B. (1976) Effect of serum proteinase inhibitors on the fertilizing capacity of rabbit spermatozoa. Fert. Steril. 27, 577-588.

Zaneveld, L.J.D., Robertson, R.T., Kessler, M. \& Williams, W.L. (1971) Inhibition of fertilization in vivo by pancreatic and seminal plasma trypsin inhibitors. J. Reprod. Fert. 25, 387-392.

Received 21 February 1983 